\title{
The influence of a second language (L2) student's goal on her attitudes and actions towards learning: a socio-cultural approach
}

\author{
Ronivaldo Braz Da Silva (DA SILVA, Ronivaldo Braz) \\ Prof. Dr. Universidade Federal de Viçosa - UFV \\ dasilva_ron@hotmail.com
}

\begin{abstract}
This article addresses the relationship between a second language (L2) student's goals and her attitude and actions towards learning to write argumentative essays in English. A case study of an upper-intermediate ESL student enrolled in a writing course in an English language institute in the US yielded data from writing samples, interviews, questionnaires, classroom observations, teacher-researcher's self-reflection diary, and transcripts of pair-work activities. Results showed that although there were contradictions between the student's positive attitudes and actions in class and her negative feelings towards writing and towards the classroom activities, her writing skills improved. Based on the socio-cultural framework of activity theory, her goal provides insight into how she responded to the course: by focusing on her life goal, she was able to set aside her dislike for writing and for the classroom activities to learn how to write in English. This suggests that understanding student goals and behaviour can help teachers improve the teaching-learning process by adapting teaching methodology to students' goals.
\end{abstract}

Keywords: second language (L2), writing in English, activity theory, student classroom behaviour, goals.

\section{Resumo}

Esse artigo trata da relação entre os objetivos de uma aluna de inglês como segunda língua e suas atitudes e ações em relação ao seu aprendizado de como escrever redações argumentativas em inglês. Foi realizado um estudo de caso de uma estudante de nível intermediário num curso de redação em um instituto de línguas nos Estados Unidos. Dados foram coletados de redações escritas pela aluna, entrevistas, questionários, observações de sala de aula, diário do professor/pesquisador, e transcrição de atividades em pares. Os resultados do estudo mostraram que, apesar de existirem contradições entre as atitudes e ações positivas da aluna em sala de aula e seus sentimentos negativos quanto a escrever redações e a atividades desenvolvidas durante o curso, houve melhora na sua habilidade de escrever. A moldura sociocultural da teoria da atividade fornece esclarecimentos sobre o seu comportamento em aula: o seu objetivo geral ajudou-a a desprezar seu desgosto por escrever redações e pelas atividades de sala de aula para que pudesse melhorar a escrita em inglês. Sugere-se, pois, que os professores prestem atenção aos objetivos e comportamento dos seus alunos para que possam melhorar o processo de ensino-aprendizagem, adaptando a metodologia aos objetivos dos alunos.

Palavras-chave: segunda língua (L2), redação em inglês, teoria da atividade, comportamento em sala de aula, objetivos. 


\section{Introduction}

As language teachers, we often see that students engage in tasks and classroom materials differently (BREEN, 1987; COUGHLAN; DUFF, 1994), but this is not often investigated. Based on socio-cultural theoretical framework, this study, part of a larger study that investigated the behaviour of nine students in an ESL writing course, discusses the attitudes and actions of one particular student, Lavelda ${ }^{1}$, and addresses why her dislike for writing and for the main activities in the composition course did not interfere with her actively participating in class nor learning from the course.

This article includes a description of the classroom-based study from which data were collected, the theoretical basis for the interpretation of Lavelda's attitudes and actions in the classroom, a short review of the literature on the use of activity theory in the L2 classroom, Lavelda's case study, a discussion on how her goal influenced her attitudes and actions in class, and implications of the current study for L2 pedagogy and theory.

\section{The study}

This classroom based study lies within the constructivist paradigm (GUBA, 1990), also referred to as interpretive (CRESWELL; MILLER, 1997). No single methodological practice was privileged (DENZIN; LINCOLN, 2000); the choice of data collection was determined largely by the context and purpose of the study. The research methodology used was ethnography. The role of the teacher-researcher was that of a participant-as-observer (BRYMAN, 2001), which included regular observations and interactions with the students in the classroom and in various micro-contexts at the school, such as in the teacher's office, secretary's office, and hallways (WATSONGEGEO, 1988). This conforms to Burns' (1996) claim that ethnographers must become immersed in a particular situation to be able to describe and interpret people's actions.

Data were collected by the teacher-researcher and by a classroom observer in a genuine intact (regular scheduled) ESL elective composition classroom, in an English language institute in the US, over a period of eight weeks. The course met twice a week, each meeting lasting one hour and forty minutes. There were 15 sessions during the term, amounting to 25 hours in total. There were nine students enrolled in the composition course. Conforming to requirements for ethics procedures, all students agreed to participate in the study, which they confirmed by signing consent forms. Data were collected from two questionnaires, teacher-researcher's self-reflection, five classroom observations, pre- and post-test essays, transcripts of five pair-work activities, and two focus group interviews (KRUEGER; CASEY, 2000). The observer interviewed the students.

A set of criteria was designed to measure student improvement in comparing pre- and post-tests. The analytic scale was chosen because it can be used to rate specific traits of students' writings separately and to mark each trait independently according to different scales (CUMMING, 1997). For an unbiased rating of the essays, an independent rater (a $\mathrm{PhD}$ student in the field of Applied Linguistics) was trained to

\footnotetext{
${ }^{1}$ The student's name in this article is a pseudonym.
} 
apply the criteria. For the purpose of reliability only, the researcher also rated the preand post-tests according to the same procedure as that followed by the trained rater. The correlation of the total scores of the trained rater and of the researcher was 0.90 .

A mixed-method design (CRESWELL; MILLER, 1997) for data analysis was adopted. The qualitative analysis aimed at providing an understanding of Lavelda's goals and of her attitudes and actions in class. The quantitative analysis was restricted to her pre- and post-test essays to verify her improvement in the course. The quantification aimed at corroborating the results of the qualitative analysis rather than at testing a hypothesis (see also FOSTER, 1998; STORCH, 2001b). Time, investigator, and methodological triangulations (DENZIN, 1970a, 1970b) were used as strategies to arrive at valid findings (DIESING, 1972), which accords with Cohen and Manion's (1994) argument that exclusive reliance on one method may bias or distort the researchers' picture of a particular slice of reality.

\section{Theoretical basis for the interpretation of Lavelda's attitudes and actions in class}

Students' attitudes and actions in the classroom can be analysed from the sociopsychological perspective of individual differences, i.e., learner's beliefs, affective states, personality, learning styles, and motivation (e.g., COHEN; DÖRNYEI, 2002; DÖRNYEI, 2001, 2003, 2005; DÖRNYEI; SKEHAN, 2003; EHRMAN, 1996; ELLIS, 1994, 2004; LARSEN-FREEMAN, 2001; SKEHAN, 1989). Although thought of as cognitive attributes, learners' individual differences are in fact substantially grounded in social values and beliefs and in past experiences. Therefore, students' attitudes in the classroom can be explained by focusing on their socio-cultural-historical make-up, which is fully articulated in the socio-cultural framework of activity theory (LANTOLF, 2000; LEONT’EV, 1978; WERTSCH, 1985).

According to activity theory, an activity is the act of doing something that is motivated by a biological need (e.g., hunger) or a culturally constructed need (e.g., education). These needs become motives for activity when directed towards a specific goal. The goal of an action is conscious (because one holds a goal in mind) and guides the actor towards fulfilling it. As in the example provided by Lantolf (2000), the feeling of hunger can motivate someone to cook. The act of cooking, however, is a goaldirected action towards fulfilling the hunger. In Lavelda's case, her need for education motivated the activity of learning to write, but her actions (e.g., registering for the composition course, attending the classes, submitting her assignments, participating in class) were goal-directed actions she took to fulfil her need, for goals are the desired end-points of an action.

Actions have operational aspects and the most fundamental level of operation is the actor's adaptation to the physical conditions where the action takes place. Conditions (DONATO; McCORMICK, 1994; LANTOLF; APPEL, 1994) can be compared to contexts, so that if the conditions change, so does the way actions are carried out. For instance, in the case of learning to write in English, changes of classroom environment, teaching methodology, instructor or peers can affect how the action is operationalised and, consequently, affect the goals pursued by the actor.

It is important to examine students' goals because they represent what students are trying to achieve in taking a course and can thus help teachers better understand their attitudes and actions (LEONT’EV, 1981). The term life goals (GILLETTE, 1994) 
is used in the discussion of Lavelda's case study, as it refers to learners' views of a language course as a useful, desirable, and valuable asset to their lives, i.e., the learners want to genuinely learn for the sake of learning. Therefore, life goals may positively influence the efforts learners make towards learning. For example, a student may use lunch breaks to do extra readings for a course or may try to put aside his/her dislike for the teacher, the subject, or a classroom activity to achieve the goal of learning.

Lavelda's goals were inferred from interviews (STORCH, 2004), from her talking while she was engaged in classroom activities (DONATO, 1988), and from questionnaires (DA SILVA, 2006). The triangulation (BURNS, 1996; COHEN; MANION, 1994; WATSON-GEGEO, 1988) of her answers in interviews and questionnaires and of the observation of her performances in class, individually and in pairs, confirmed Lavelda's goals.

Below is a discussion of the use of activity theory in the second language classroom.

\section{Review of the literature}

A number of researchers have employed the socio-cultural framework of activity theory to discuss in-the-classroom events. For example, Coughlan and Duff (1994) showed that the same task does not yield similar results when performed by different students or even when performed by the same students on two different occasions. They argued that the outcomes of classroom activities are influenced by the students' motives and goals. By addressing the issue of individual differences in L2 achievement, Gillette's (1994) study revealed that learners' achievements were largely dependent on their goals, and that these goals depended on the learners' social history and the practical value they attributed to the second language they were learning.

A study conducted by McKay and Wong (1996) showed that there is a relationship between the students' individual histories and their effort in learning the target language. McKay and Wong also argued that the learners' historically specific needs, desires, and negotiations are the constituent parts of the students' lives and are the determinant of their efforts to learn the target language. Roebuck's (2000) study showed evidence that learners shape their activities based on their own particular goals, motives, and socio-cultural histories.

Norton (2001) addressed the conditions under which learners withdrew entirely from participation in ESL classrooms and noted that these learners' socio-cultural histories aided in explaining their behaviour. Norton argued that the student's reconstruction of their past as an imaginative construction of the future (WENGER, 1998) conflicted with their participation in the ESL classes. Further, based on the presupposition that learners' constantly organise and reorganise a sense of who they are and how they relate to the social world when they practice the target language (PEIRCE, 1995), Norton (2001) argued that the conditions under which the teachinglearning process takes place may affect students' learning.

Spence-Brown (2003) used activity theory to examine task-in-process and factors that influence this process. Similar to Coughlan and Duff (1994), Spence-Brown (2003) argued that students did not entirely adopt the frames presented to them by their teachers when performing classroom tasks. Spence-Brown also argued that the students' backgrounds and reasons for taking the course were influential in this process. Storch (2004) utilised the analytical framework of activity theory in order to explain 
differences in patterns of dyadic interactions in an ESL class and noted that it is the learners' definition of the situation and, specifically, their perceived goals and roles that determine how an activity is carried out. Activity theory has also been used to explain why students engage in tasks and classroom materials differently (DA SILVA, 2006).

These studies used activity theory to explain how students responded to tasks or how students oriented themselves to the activities they performed in the classroom, based on their individual motives and goals for participating in these activities. The results confirmed that students have different motives and goals that influence their approach to tasks, and that these motives and goals are related to their individual sociocultural histories. In summary, these studies showed that the learners' motives, goals, and socio-cultural-historical background assist in the interpretation of the learners' attitude towards their learning, classroom events, and outcome. These studies also showed that the conditions under which teaching takes place may influence students' learning. What has remained unexplored, however, is the influence of goals and of the learning conditions in helping students ignore their dislike of a given skill (e.g., writing) and the major tasks involved in learning the skill, and yet enrol in a course, actively participate in, and learn from it.

Although activity theory does not provide a clear-cut methodology for recognising, delineating, and scrutinising activities (BANNON, 1997), I derived an adaptation of Engeström's (1993) principles of activity theory to analyse Lavelda's case, which involves the following procedures. First, I discuss Lavelda's background to compare her previous learning experiences with the composition course and to identify her goals for taking the course. Second, I discuss how she carried out activities in the classroom and compare it with her responses in the interviews, thus providing a further indication of her goals. Third, I discuss how Lavelda's goal for taking the course explains the contrast between her attitudes and actions in the classroom and her real feelings towards writing and the course activities, which in turn explains her positive response to the course and her outcome.

\section{Lavelda's background}

Lavelda is from Sweden. Of the nine students enrolled in the composition course, Lavelda was an older student, being one of only two in their mid-thirties. At lunchtime, I often saw her sitting outside or in an empty classroom doing school work alone. Being the only student from Sweden, she may have faced difficulties in interacting with the other students, who were mainly from Asia, Spanish-speaking countries in Central or South America, the Middle East, and Western Africa (Togo).

Lavelda started the composition course at the beginning of her second week in the United States. This was her first experience living and studying in an English speaking country. In addition to the composition course, she was enrolled in Reading/Writing (focus on paragraphing), Conversation/Listening, and Grammar courses. Her previous experience of studying English was in a public school in Sweden for over four years, but as shown below, she claimed that she had not been taught how to structure an essay before the composition course. She also said she had learnt a lot from the course but found it a bit difficult:

[...] We haven't been taught very much how to read \{write $\}$ an essay. Just how to read $\{$ write $\}$ it down with, with what we are thinking about not that we have 
to have a conclusion, or a topic about it. So, I have learned a lot over here. [...] It's difficult to put my opinions on the writing, in the right paragraph. So, it's connected to the topic and also got be in the conclusion [...] I think it's a little bit hard for me because I haven't been teached how to write an essay before, so it's taking a long time for me to write an essay and I have to think a lot and dig deeper and I have to spend more time. (Interview 1: Week 5)

Lavelda recognised her previous English writing learning experience, in which she just had to write down her thoughts, as deficient. The composition course, on the other hand, challenged her to not only write down her thoughts but also to structure them for the purpose of the essay. She considered the material taught in the course challenging important not only for her college aspirations but, most importantly, for her life in general, as she realised the usefulness of the course for work purposes after college:

Because you need to know how to write, even it is just a short paragraph. You need to know how to put the sentences in order, so this is absolutely something that I have to have with me when I go to college or when I go to work or something. (Interview 2: Week 7)

\section{Lavelda in the classroom}

Lavelda wore a constant frown as if worried about something and her facial expression when looking at the blackboard or performing exercises showed deep concentration. She seemed impatient and tense at times. She was doing well in the course, but every time I asked her if she was able to understand the subject matter being taught, she said so-so and that the course was difficult for her. Even so, Lavelda participated actively in class, as portrayed in the following observation:

As the teacher goes through the activity with the class, he asks Joe and Lavelda directly if they agree with the answers, and they do. [...] Lavelda and Calvin all nod consistently to interact with teacher. [...] For the next set of sentences, Lavelda [...] and Adam all volunteer answers simultaneously aloud. [...] Lavelda asks a vocabulary question: What is an assumption? [...] Students answer in unison again when teacher asks question: Lavelda, George, Brandon, Adam. [...] For the next sentence, Lavelda volunteers an answer [...]. (Observation 1: Week 2)

[...] and Lavelda are all genuinely interested - they are nodding, following along on OHP, board, handouts and taking notes. [...] Lavelda is looking intently—seems to be concentrating. (Observation 2: Week 4)

She had a positive attitude towards the course, evidenced by her appreciation for the way the classes were taught, for the course materials, and by her mentioning of the features she learnt from the classes:

This class has learn me a lot how to read \{write an essay. So, ah, the point that he's shown us how to, how to write a good essay, about the topic and all the summary and everything... it helps a lot to do a good essay. (Interview 1: Week 5) 
It $\{$ the course $\}$ helped me a lot with the order and the, with the, the need to have an, a conclusion that explains what the topic was about. So, that helped me a lot. It is easier to write an essay now than it was before. (Interview 2: Week 7)

I have improved my writing and I have learned how to organise an essay. (Questionnaire 2: Week 7)

Lavelda also made constructive suggestions to enhance the classes:

It's easier to do write a good essay if you have a lot of choice, something, some topics you don't like to and don't have experience from and don't know much about. So, I would like to have more choices on the topic but it's good. (Interview 1: Week 5)

We had to vote in class what the topic was to be about. And that part I liked because sometimes if it's a topic that you like, it's easier to write, for you to write an essay because that's an interesting thing for you. So, you can come up with more ideas and... But if you have a topic you're so-so with, so it's harder for you to come up with something that's going to interest the, the reader. (Interview 2: Week 7)

She said she benefited from the teacher's feedback and asked for more feedback:

I think I have learned more after his feedback on the essay but I would like to have a little bit more of that because sometimes it's hard to understand what he means in some words. So, maybe a little bit more feedback. But it helped me a lot. (Interview 2: Week 7)

Additionally, Lavelda was aware of her areas of weaknesses:

I know that I have to improve my explanations in an essay and give more examples, more details so the reader... so I can get the readers' attention what I am going to write about. So, that's something I need to improve. (Interview 2: Week 7)

Furthermore, she expressed frustration with the pair-work activities, which seemed rooted in her concern of not being able to understand her classmates, as opposed to having personal issues with them or disliking a particular pair activity. The following comment was made at the end of the course, three weeks after the last pair-work she participated in:

For me it's difficult to work in pair with other because sometimes I don't understand. The pair talk fast and, and a sometimes it's difficult to understand and... but I have learned a lot. So, sometimes it's easier for me to do it by myself because I don't want to ask that person again. What did you say? What did you say? And, ah, maybe, that person feels bad [...]. (Interview 2: Week 7)

Nevertheless, Lavelda participated actively and collaboratively with all four partners in the pair-work activities. There were several salient features throughout their interactions, such as repetitions, confirmations, elaborations, questions, corrective feedback in the form of recasting, affective markers, collaborative dialogue, collective scaffolding, involvement markers, cumulative and exploratory talks, phatics, and 
directing signals, which have been identified by other researchers as evidence of engagement and collaboration (e.g., DONATO, 1994; DONATO, LANTOLF, 1990; DUFF, 1995, 1996, 2000; MCCORMICK; DONATO, 2000; MERCER, 1995; MESKILL, 1993; OHTA, 2000, 2001; SCHIFFRIN, 1987; STORCH, 2001a; SWAIN, 2000; TANNEN, 1987, 1989; VILLAMIL; De GUERRERO, 1996; WEGERIF; MERCER, 1996; WOOD et al., 1976).

The observer's notes also provided evidence of Lavelda's collaboration:

They went step-by-step through each phase of the worksheet, coming to an agreement before writing anything down. Then, one wrote while the other looked and gave examples of what to write. [...] They seemed to collaborate totally, step-by-step, and to really share their knowledge. (Observer's notes: Week 4)

They really seem to enjoy working together-there's lots of smiling, nodding, etc. They go sentence by sentence together through the chart. [...] They really collaborate with one another, listen to each other and show a great deal of respect for each other's opinion. (Observer's notes: Week 5)

Ultimately, Lavelda earned an "A" in the composition course and had an overall improvement of 10 points from pre- to post-test. According to the criteria designed for rating the pre- and post-test essays, in which the lowest possible grade was 8 points and the highest 40 points, Lavelda scored 18 on the pre-test and 28 on the post-test.

Interestingly, at the end of the course, Lavelda said that she did not like to write, either before or after taking the composition course:

I haven't been interested in writing before and not much now, now either but, it helped me a lot with the order and the, with the, the need to have an, a conclusion that explains what the topic was about. (Interview 2: Week 7)

\section{Discussion of Lavelda's attitudes and actions based on her goal}

This discussion addresses how Lavelda's attitudes and actions can be explained in terms of her goal for taking the course. Her overriding motive for taking the composition course was the culturally constructed need for education, specifically, to learn to write. Her enrolling in the composition course, attending classes, participating in classroom activities, submitting assignments, and studying for and taking exams were goal-directed actions. Her goal was confirmed from the triangulation of her answers to questionnaires and interviews and from her talk while she was engaged in classroom activities. She overtly expressed her goal by saying that she judged the material taught in the composition course important for her college aspirations and for her life in general, as she realised the usefulness of the course for work purposes after college.

Her attitudes and actions towards the course and her learning can be explained by the notion of life goals (GILLETTE, 1994), in which learners view a language course as useful, desirable, and a valuable asset to their lives. Consistent with life goals having a positive influence on the efforts students make toward learning (GILLETTE, 1994), 
Lavelda was often seen during lunch breaks doing school work. This indicates that she wanted to learn, which was reinforced by her asking for extra feedback on the essays she wrote. Further evidence of the positive influence of her life goal on her attitudes was her awareness of her areas of weaknesses, which indicates that she had been monitoring her learning by observing and following the feedback provided on her essays. The positive influence can also be seen through her active participation in class, such as her collaboration in the pair-work activities and submission of all assignments.

However, there were contradictions between Lavelda's positive attitudes and actions in the classroom and her expressed antipathy towards the main tasks she performed in class, namely, writing and the pair-work activities. She said that she did not like writing, either before or after the composition course, and voiced her frustration with the pair-work activities. Despite this dislike of writing itself and the classroom activities, her life goal maintained a positive influence on her attitudes and drove Lavelda to persist in learning (GILLETTE, 1994).

Furthermore, the conditions (DONATO; McCORMICK, 1994; LANTOLF; APPEL, 1994) under which the course took place had an influence on her attitudes and actions. Lavelda compared her previous learning to write experiences with the composition course and noticed that although the latter posed a challenge for her, it taught what she needed to learn for college and professional purposes. Further, she demonstrated appreciation for the course materials, the way the classes were conducted, and the feedback provided by the teacher. These conditions allowed her to realise how the course would contribute to her life goal, resulting in a positive impact on her attitudes and actions.

The finding of this study, that Lavelda's actions were goal oriented, corroborates Coughlan and Duff's (1994) finding that students' goals influence the outcome of activities in the classroom, and McKay and Wong's (1996) argument that students' goals determine their efforts to learn the target language. Furthermore, the result of this study confirms Roebuck (2000) and Spence-Brown's (2003) assertion that learners shape their activities based on their own particular goals. Ultimately, congruent with Gillette's (1994) findings that students' goals play an important role in their learning, this study found that Lavelda's goal had an impact on her learning, as evidenced by the "A" she earned in the composition course and her 10-point improvement from pre- to post-test.

Since goals are related to learners' social history and the use value they attribute to the second language they are learning (GILLETTE, 1994), Lavelda's attitudes and actions in the classroom support the activity theory premise that students' responses to tasks are influenced by their individual socio-cultural histories. Lavelda's goal to learn is intrinsically connected to her belief that knowing how to write well in English is useful and desirable for her life in general, and this belief is built from life experiences. Congruent with the results of other studies (see for example COUGHLAN; DUFF, 1994; McKAY; WONG, 1996; ROEBUCK, 2000; STORCH, 2004), Lavelda's sociocultural history explains her awareness of the benefits of the composition course, which, in turn, explains her behaviour in the composition classroom. In summary, the findings of this study demonstrate the applicability of activity theory in explaining students' attitudes and actions in the classroom based on their goals.

Despite the contradictions between Lavelda's attitudes and actions in class and her feelings towards writing and classroom activities, she earned an " $A$ " in the composition course and had a 10-point improvement from pre- to post-test. On the one hand, she chose to enrol in an elective writing course, actively participated in it 
(particularly in the pair-work activities), fulfilled all course requirements, provided constructive criticisms to improve the classes, and said she learnt from the course. On the other hand, she stated her dislike for writing, before and after the course, and her frustration with the pair-work activities. These conflicts, if taken at face value, would add to her difficulties as a novice learner in essay writing. However, they did not interfere with her gaining from the course.

Lavelda's attitudes and actions in the classroom, as explained in terms of the principles of the socio-cultural framework of activity theory, were goal-oriented actions that aimed at fulfilling her goal to genuinely learn to write well and prepare herself for life, academically and professionally. As a consequence, her goal had a positive impact on her attitudes and actions towards her learning and helped her set aside her dislike of writing and of pair-work, for she recognised the importance of the material taught as an asset for life.

\section{Implications for theory and L2 pedagogy}

This study confirmed that activity theory is a useful tool to explain students' attitudes and actions in the classroom in terms of their goals. Through activity theory, Lavelda's goal provided insights into why she responded to the course the way she did. Despite contradictions between her attitudes and actions in the classroom and her expressed feelings about the course, by focusing on her life goal, Lavelda was able to set aside her dislike for writing and for the classroom activities to learn how to write in English.

Pedagogically, an understanding of the students' goals can contribute to teachers' understanding of the way students behave in the classroom (LEONT'EV, 1981). This then gives teachers awareness of what can potentially improve the teachinglearning process, as they can adapt the teaching methodology to the students' goals. Additionally, in the case of students with a goal other than that of learning from the course, even if teachers are not able to influence or change those goals, they may be able to improve the outcomes by steering the students on a course for maximum goal achievement.

\section{References}

BANNON, Liam. Activity theory. 1997. Disponível em: http://wwwsv.cict.fr/cotcos/pjs/TheoreticalApproaches/Actvity/ActivitypaperBannon.htm. Acesso em: 4 mar. 2005.

BREEN, Michael P. Learner contribution to task design. In: CANDLIN, Christopher N.; MURPHY, Dermot F. (Eds.). Language learning tasks. Lancaster practical papers in English language education, v. 7. Englewood Cliffs, NJ: Prentice-Hall International, 1987. p. 23-46.

BRYMAN, Alan. Social research methods. Oxford, UK: Oxford University Press, 2001. 
BURNS, Robert B. Introduction to research methods. 3rd ed. Melbourne, Australia: Addison Wesley Longman, 1996.

COHEN, Andrew D.; DÖRNYEI, Zoltan. Focus on the language learner: motivation, styles and strategies. In: SCHMITT, Norbert. (Ed.). An introduction to applied linguistics. London, UK: Arnold, 2002. p. 170-190.

COHEN, Louis; MANION, Lawrence. Research methods in education. 4th ed. London, UK: Routledge, 1994.

COUGHLAN, Peter; DUFF, Patricia A. Same task, different activity: analysis of SLA task from an activity theory perspective. In: LANTOLF, James P.; APPEL, Gabriela (Eds.). Vygostskian approaches to second language research. Norwood, NJ: Ablex Publishing Corporation, 1994. p. 173-193.

CRESWELL, John W.; MILLER, Gary A. Research methodologies and the doctoral process. In: GOODCHILD, Lester F.; GREEN, Kathy E; KATZ, Elinor L.; KLUEVER, Raymond C. (Eds.). Rethinking the dissertation process: tackling personal and institutional obstacles. San Francisco, CA: Jossey-Bass Publishers, 1997. p. 33-46.

CUMMING, Alister. The testing of writing in a second language. In: CLAPHAM, Caroline; CORSON, David. (Eds.). Language testing and assessment. Encyclopedia of Language and Education v. 7. London: Kluwer Academic Publications, 1997. p. 51-63.

DA SILVA, Ronivaldo B. An investigation of the relationship between L2 learners' goals and their attitudes towards their learning. 2006. Unpublished doctoral dissertation - The University of Melbourne, Melbourne, VIC: Australia, 2006.

DENZIN, Norman K. The research act: a theoretical introduction to sociological methods. Chicago, IL: Aldine Publishing Company, 1970a.

Sociological methods: a sourcebook. London, UK: The Butterworth Group, 1970b.

DENZIN, Norman K.; LINCOLN, Yvonna S. The discipline and practice of qualitative research. In: DENZIN, Norman K.; LINCOLN, Yvonna S. (Eds.). Handbook of qualitative research. 2nd ed. Thousand Oaks, CA: Sage Publications, 2000. p. 1-28.

DIESING, Paul. Patterns of discovery in the social sciences. London, UK: Routledge and Kegan Paul, 1972.

DONATO, Richard. Beyond group: a psycholinguistic rationale for collective activity in second-language learning. 1988. Tese de doutorado - University of Delaware, Newark, 1988.

Collective scaffolding in second language learning. In: LANTOLF, James P.; APPEL, Gabriela. (Eds.). Vygotskian approaches to second language research. Norwood, NJ: Ablex Publishing Corporation, 1994. p. 33-56. 
DONATO, Richard; LANTOLF, James P. The dialogic origins of L2 monitoring. Pragmatics and Language Learning, v. 1, p. 83-98, 1990.

DONATO, Richard; McCORMICK, Dawn. A sociocultural perspective on language learning strategies: the role of mediation. The Modern Language Journal, v. 78, n. 4, p. 453-464, 1994.

DÖRNYEI, Zoltan. Motivational strategies in the language classroom. Cambridge: Cambridge University Press, 2001.

Attitudes, orientations, and motivations in language learning: advances in theory, research, and applications. Language Learning, v. 53, n. 1, p. 1-32, 2003.

The psychology of the language learner: individual differences in second language acquisition. Mahwah, NJ: Lawrence Erlbaum Associates, Inc., Publishers, 2005.

DÖRNYEI, Zoltan; SKEHAN, Peter. Individual differences in second language learning. In: DOUGHTY, Catherine J.; LONG, Michael H. (Eds.). The handbook of second language acquisition. Malden, MA: Blackwell Publishing, 2003. p. 589-630.

DUFF, Patricia. A. An ethnography of communication immersion classrooms in Hungary. TESOL Quarterly, v. 29, n. 3, p. 505-537, 1995.

Different languages, different practices: socialization of discourse competence in dual-language school classrooms in Hungary. In: BAILEY, Kathleen M.; NUNAN, David. (Eds.). Voices from the language classroom: qualitative research in second language education. Cambridge: Cambridge University Press, 1996. p. 407-433.

Repetition in foreign language classroom interaction. In: HALL, Joan K.; VERPLAETSE, Lorrie S. (Eds.). Second and foreign language learning through classroom interaction. Mahwah, NJ: Lawrence Erlbaum Associates, 2000. p. 109-138.

EHRMAN, Madeline E. Understanding second language learning difficulties. Thousand Oaks, CA: Sage Publications, 1996.

ELLIS, Rod. The study of second language acquisition. Oxford: Oxford University Press, 1994.

Individual differences in second language learning. In DAVIES, Alan; ELDER, Catherine. (Eds.). The handbook of applied linguistics. Malden, MA: Blackwell Publishing, 2004. p. 525-551.

ENGESTRÖM, Yrjo. Development studies of work as a test-bench of activity theory. In: CHAIKLIN, Seth; LAVE, Jean. (Eds.). Understanding practice: perspective on activity and context. Cambridge, UK: Cambridge University Press, 1993. p. 64-103.

FOSTER, Pauline. A classroom perspective on the negotiation of meaning. Applied Linguistics, v. 19, n. 1, p. 354-375, 1998. 
GILLETTE, Barbara. The role of learner goals in L2 success. In: LANTOLF, James P.; APPEL, Gabriela. (Eds.). Vygostskian approaches to second language research. Norwood, NJ: Ablex Publishing Corporation, 1994. p. 195-213.

GUBA, Egon G. The alternative paradigm dialog. In: GUBA, Egon G. (Ed.). The paradigm dialog. Newbury Park, CA: Sage Publications, 1990. p. 17-27.

KRUEGER, Richard A.; CASEY, Mary Anne. Focus groups: a practical guide for applied research. 3rd ed. Thousand Oaks, CA: Sage Publications, 2000.

LANTOLF, James P. Introducing sociocultural theory. In: (Ed.). Sociocultural theory and second language learning. Oxford, UK: Oxford University Press, 2000. p. 126.

LANTOLF, James P.; APPEL, Gabriela. Theoretical framework: an introduction to Vygotskian approaches to second language research. In: (Eds.). Vygotskian approaches to second language research. Norwood, NJ: Ablex Publishing Corporation, 1994. p. 1-32.

LARSEN-FREEMAN, Diane. Individual cognitive/affective learner contributions and differential success in second language acquisition. In: BREEN, Michael P. (Ed.). Learner contributions to language learning: new directions in research. Harlow, England: Longman, 2001. p. 12-24.

LEONT'EV, Alexei N. Activity, consciousness, and personality. Englewood Cliffs, NJ: Prentice-Hall, 1978.

The problem of activity in psychology. In: WERTSCH, James V. (Ed.). The concept of activity in Soviet psychology. New York: M. E. Sharpe, 1981. p. 37-71.

McCORMICK, Dawn E.; DONATO, Richard. Teacher questions as scaffolded assistance in an ESL classroom. In: HALL, Joan K.; VERPLAETSE, Lorrie S. (Eds.). Second and foreign language learning through classroom interaction. Mahwah, NJ: Lawrence Erlbaum Associates, 2000. p. 183-201.

McKAY, Sandra L.; WONG, Sau-Ling C. Multiple discourses, multiple identities: investment and agency in second-language learning among Chinese adolescent immigrant students. Harvard Educational Review, v. 66, n. 3, p. 577-608, 1996.

MERCER, Neil. The guided construction of knowledge. Talk amongst teachers and learners. Clevedon, UK: Multilingual Matters, 1995.

MESKILL, Carla. ESL and multimedia: a study of the dynamics of paired student discourse. System, v. 21, n. 3, p. 323-341, 1993.

NORTON, Bonny. Non-participation, imagined communities and the language classroom. In: BREEN, Michael P. (Ed.). Learner contributions to language learning: new directions in research. Harlow, England: Longman, 2001. p. 159-171. 
OHTA, Amy S. Rethinking recasts: a learner-centered examination of corrective feedback in the Japanese language classroom. In: HALL, Joan K.; VERPLAETSE, Lorrie S. (Eds.) Second and foreign language learning through classroom interaction. Mahwah, NJ: Lawrence Erlbaum Associates, 2000. p. 47-71.

Second language acquisition processes in the classroom: learning Japanese. Mahwah, NJ: Lawrence Erlbaum Associates, 2001.

PEIRCE, Bonny N. Social identity, investment, and language learning. TESOL Quarterly, v. 29, n. 1, p. 9-31, 1995.

ROEBUCK, Regina. Subjects speak out: how learners position themselves in a psycholinguistic task. In: LANTOLF, James P. (Ed.). Sociocultural theory and second language learning. Oxford, UK: Oxford University Press, 2000. p. 79-95.

SCHIFFRIN, Deborah. Discourse markers. Cambridge, UK: Cambridge University Press, 1987.

SKEHAN, Peter. Individual differences in second-language learning. London, UK: Edward Arnold, 1989.

SPENCE-BROWN, Robyn. Authentic assessment? The implementation of an "authentic" teaching and assessment task. 2003. Tese de doutorado. The University of Melbourne, Melbourne, VIC: Australia, 2003.

STORCH, Neomy. How collaborative is pair work? ESL tertiary students composing in pairs. Language Teaching Research, v. 5, n. 1, 29-53, $2001 \mathrm{a}$.

An investigation into the nature of pair work in an ESL classroom and its effect on grammatical development. 2001. Tese de doutorado. The University of Melbourne, Melbourne, VIC: Australia, 2001b.

Using activity theory to explain differences in patterns of dyadic interactions in an ESL class. The Canadian Modern Language Review, v. 60, n. 4, p. 457-480, 2004.

SWAIN, Merrill. The output hypothesis and beyond: Mediating acquisition through collaborative dialogue. In: LANTOLF, James P. (Ed.). Sociocultural theory and second language learning. Oxford, UK: Oxford University Press, 2000. p. 97-114.

TANNEN, Deborah. Repetition in conversation: toward a poetics of talk. Language, v. 63, n. 3, p. 574-605, 1987.

Talking voices: repetition, dialogue, and imagery in conversational discourse. Cambridge: Cambridge University Press, 1989.

VILLAMIL, Olga S.; De GUERRERO, Maria C. M. Peer revision in the L2 classroom: social-cognitive activities, mediating strategies, and aspects of social behaviour. Journal of Second Language Writing, v. 5, n. 1, 51-75, 1996. 
WATSON-GEGEO, Karen A. Ethnography in ESL: defining the essentials. TESOL Quarterly, v. 22, n. 3, p. 575-592, 1988.

WEGERIF, Rupert; MERCER, Neil. Computers and reasoning through talk in the classroom. Language and Education, v. 10, n. 1, p. 47-64, 1996.

WENGER, Etienne. Communities of practice: learning, meaning, and identity. Cambridge, UK: Cambridge University Press, 1998.

WERTSCH, James. V. Vygotsky and the social formation of mind. Cambridge, MA: Harvard University Press, 1985.

WOOD, David; BRUNER, Jerome S.; ROSS, Gail. The role of tutoring in problem solving. Journal of Child Psychology and Psychiatry and Allied Disciplines, v. 17, p. 89-100, 1976. 